\title{
Building in Sustainability, Social Responsibility and Value Co- creation
}

\author{
Sergio Biggemann ${ }^{1}$ \\ University of Otago School of Business \\ New Zealand \\ Martin Williams \\ University of Technology, Sydney \\ Australia \\ Gunn Kro \\ University of Otago School of Business \\ New Zealand
}

${ }^{1}$ Corresponding author. sergio.biggemann@otago.ac.nz; Phone: +64 3479 8467; Fax: +64 34798172 


\title{
Building in Sustainability, Social Responsibility and Value Co- creation
}

\begin{abstract}
Purpose

This paper addresses the question of how value can be created through social responsibility programs or other means, so that sustainability is achieved through increasing stakeholders' participation in the process of design and selection of such programs, so that transparency is maximised and trust can be built with the lasting benefits of co-creation of value.

\section{Design/Methodology/Approach}

This paper studies the relationship between sustainability, corporate social responsibility, and value co-creation based on qualitative research data gathered from two embedded case studies. The first case study in a large mining company operating in New Zealand and the second case study is based on the New Zealand Merino Company.

\section{Findings}

Findings of this research suggest that sustainability is built with the participation of many interconnected entities, that is, suppliers, manufacturers, retailers, or more generally stakeholders whose actions are fostered by social responsibility that fuels the pride, trust, and consistency of the members of the value chain. Value in all forms -functional value, hedonic value, symbolic value and cost value- is a recurrent theme in this research data; however it is value co-creation, working together, living up to the values that their products and services promise that ultimately supports sustainability.

\section{Originality/Value}

This paper shows how the scope of sustainability has broadened from environmental matters to include other topics such as good corporate citizenship, business relationships and the 
value that is created and shared, not only with shareholders, but also within a wider community of stakeholders.

In Case Study 1, interaction is facilitated by an existing working relationship, then, in subsequent interaction both parties utilise each other's resources in co-creating value. The involvement of the stakeholder in the project, legitimises the company's actions while making the stakeholder feel proud of the project outcome, thus, the company is seen as a good partner and thus the relationship becomes stronger. Later, the successfully completed project serves as the context of interaction where the parties are able to discuss and resolve problems that otherwise might be irreconcilable.

While consistency and trust are well known dimensions of business relationships, pride, not previously studied, became a relevant issue in Case study 2. Pride emerges from the feeling of ownership value that co-created activities nurture. Pride, strengthens the network links promoting business bottom-line viability at little or no cost. It also reduces the parties' motivation for opportunistic behaviour. A virtual circle between value co-creation and the perception of value that a project delivers, derives from integrity. Integrity makes the company boundaries less sharp, and thus increases the parties' ownership of the outcomes that the operations of the company deliver.

\section{Keywords:}

Sustainability, Social Responsibility, Value co-creation, Pride, Integrity

\section{Introduction}

Porter and Kramer (2011) discuss the perverse effects of corporate social responsibility, arguing that the more the businesses embrace corporate social responsibility the more they 
are blamed for society's failures. The reason for this, Porter and Kamer continue, is that social responsibility programs increase the visibility of companies, and, instead of improving their image, companies are perceived to be prospering at the expense of the broader community. Thus the community construes companies' actions as doing too little when the aim was in reality to be perceived as doing good, which ultimately should result in enhanced business viability. So the expected positive reactions that corporate social responsibility programs (CSR's) are designed to create may turn unexpectedly negative. Although companies have moved from the Friedman's (1962) perspective which proclaims that the only obligation of businesses is to create wealth for their stakeholders, the adoption of social responsibility initiatives has not increased their ability to secure the wider benefits of sustainability

Sustainability has been on top of the international agenda in the last few years. While pundits and practitioners have discussed ad nauseam the importance of issues such as water conservation, energy production, and waste control, and though corporate strategies have developed in response to increased environmental regulations (Menon \& Menon, 1997), sustainability goes beyond environmental aspects only. Carroll (1979) argues that senior staff started taking corporate actions beyond the economic interests of the firm, this prompted obligations of businesses towards society to became more transparent in relation to their actions. Although most large corporations have adopted social responsibility programs and interest groups have gained ground to influence long term business strategies (Bowd, Bowd, \& Harris, 2006), Clarkson (1995) concludes that corporate actions should create value to the community through consultation with stakeholders. However, value is not embedded in objects, instead it is co-created in interaction with other parties (Ramaswamy, 2008; Vargo, 2008). Thus, companies’ actions may not foster sustainability unless beneficiaries are included in the early stages of social responsibility programs. 
Our research addresses the question of how value can be created through social responsibility programs or other means, so that sustainability is achieved through increasing stakeholders participation in the process of design and selection of such programs, so that transparency is maximised and trust can be built with the lasting benefits of co-creation of value.

This paper presents findings of two embedded case studies (Yin, 2003), one in the mining industry and the other in the fashion industry.

\section{Literature review}

Delivering superior value in business involves the participation of a large number of parties amplifying the difficulties of coordinating business interaction (Anderson, Kumar, \& Narus, 2007). Failures to coordinate actions in complex value chains can translate into massive recalls of products that companies may be pressured into instigating. On the consumer side the levels of information available promoted by the advancement of information technology can expose, in short time frames, any problems a company might have. Even more importantly, increased information availability has promoted the emergence of new groups of consumers that proactively seek information about the business practices, as well as probe the behaviour of the suppliers of those businesses. This means consumers are now capable of seeing further into suppliers' extended networks, as well as investigating the behaviour of their members.

Businesses' reactions to consumers' enhanced ability to scrutinise their operations are diverse. They vary from keeping their suppliers as secret as possible, (e.g., Apple), to forcing them to comply to their norms and regulations, (e.g., Wal-Mart). Others like Mattel have tried for years to establish global operation rules, only to face the naked truth that one party's opportunistic behaviour is enough for their whole system to collapse. In a worst-case 
scenario, whenever unsuitable products for consumption reach the market, these companies have instigated massive product recalls (e.g., Volkswagen). Some have even had to explain to customers why parts or their complete offerings have been produced in sweat shops (e.g., Nike). Consequences of these problems seriously affect business viability; each time a business has had a major supply chain disruption of this nature its shares have plummeted by 9 per cent while its sales have fallen on average 4 per cent (PriceWaterhouseCoopers, 2008). The loss of equity and reputation these problems have created are difficult to turn around. The response has been to establish corporate social responsibility programs (CSR) within their communities (Williams, Buttle \& Biggemann, 2012) to enhance or shore-up their corporate reputation.

These strategies aim to demonstrate behaviour that says 'we are good citizens'. Businesses depend on the communities where they operate and therefore they need to show they care about them. CSR initiatives are broadly utilised, however, they can deliver diverse results. The best thought-out CSR programs, due to existing problems between the company and some stakeholders that such programs cannot resolve may deliver little benefit; worse still, if other members of the value chain happen to have problems with their own stakeholders, for other related companies results may be negative. For instance, when Mattel recalled millions of lead tainted toys Mattel suffered the consequences despite the origin of the problem lying with a subcontractor. Thus, in designing CSR programs attention to those companies outside the immediate value chain may be desirable.

Porter (1985) introduces the concept of the value chain looking at the processes that products or services go through in their transformation until they reach their final destination; typically the end consumer. Porter's work has been influential in the study of the supply chain that in 
modern times includes the concept of a demand chain that has the ultimate objective of meeting end users' needs with suppliers’ offerings (Harrison, Lee, \& Neale, 2005), while in keeping with efficiencies alongside the chain, that are a source of competitive advantage.

The value chain focuses on identifying consumer's wants and needs and then rallying resources to create a product or service that meets these needs. The value chain is, therefore, about how value is created. Nevertheless, Smith and Colgate (2007) argue that little is said on what value should be created, or "what constitutes a well-defined product concept from a value perspective” (p.7), thus these authors offer a way in which the benefits of a sustainability strategy may be considered within the chain.

Although value is in principle expressed in monetary terms, (i.e., cost/sacrifice-type value), research shows other forms of value that appear to be relevant for the concept of value chain integrity. That is, relational synergies occur when a long-term relationship between two organizations delivers more collective value than the value that the organizations acting independently could deliver (Borys \& Jemison, 1989; Thorelli, 1986). Value created in interaction may result from sharing resources, knowledge, and technology and may also include sustainability within the members of the chain along the way to ultimate consumption. An alternative concept is that value is not fully contained within a product or service, but is rather it is realised in use. Prahalad and Ramaswamy (2004) propose that unique value can be co-created by involving the end user through the process of value creation, value is then in the co-creation experience rather than lying solely in the physical or service offering. 
Definitions of value are grounded in the interactivity between subject and object, (see for instance Holbrook, 1999), which, in the service marketing arena is utilised to explain value as realized when a service is used. Sandstorm, Edvardsson, Kristensson, and Magnusson (2008) argue that users are co-creators and judges of the service value whereas Flint (2006) describes the dynamics of value creation as the customer valuing the product, starting with the idea of using the product at the pre-purchase stage followed with valuing the purchase experience at the purchasing transaction stage, then to continue valuing owing the product at the postpurchase stage, concluding with de-valuing owing the product, which may terminate with commencement of a new buying cycle. Smith and Colgate (2007) offer a practical framework to conceptualise value comprised by four categories: functional/instrumental, experiential/hedonic, symbolic/expressive and cost/sacrifice, sustainability arguably lying betwixt the symbolic/expressive and experiential/hedonistic modes.

These forms of value imply the participation of supplier and customer in both assessing, as well as realising the value of the offering. To-day customers tend to scrutinise how value is created so that companies have reacted by putting programs in place that ensure no ethical issues exist in the elaboration of their offerings, where the literature refers to these actions as customer social responsibility (CSR).

While companies show concern about sustainability and report on their social actions and achievements through corporate websites and annual reports, Baumgartner and Ebner (2010) argue that the objective of such publications and the focus of these social programs is unclear. Sustainability strategies may be guided by internal and external sustainability orientation wherever the organisation contributes to value along the chain. Internally, a company may be 
able to plan and communicate its aims, however, externally the company may be reliant on the actions and reactions of other parties that form the networks in which they operate. Current thinking about sustainability recognises the importance of identifying and understanding the needs and interests of all stakeholders and the value that is created in the interaction with them. However, value assessment is inherently difficult, particularly because of the importance given to economic value on which most research on business cases is focussed. The value of sustainability per se is difficult to quantify (Salzmann, IonescuSomers, \& Steger, 2005) because economic value only materialises in the long term. In fact, Spence and Bourlakis (2009) argue that there is no evidence of positive results from corporate citizenship activity. Thus quantifying the value of sustainability programs and social projects is not the only difficulty; identifying the beneficiaries of such value, if it exists at all, is also an issue. So, the question is not only about how much value is created, but defining how it is distributed.

The roles and influence of stakeholders in management of sustainability and social projects is not only about value generation and distribution. Buysse and Verbeke (2003), who based their research on environmental strategies, highlight the linkages between the projects and the management of stakeholders: proactive environmental strategies are also associated with deeper and broader coverage of stakeholders, they argue. Miles, Munilla, and Darroch (2006) recommend proactively engaging specific stakeholder groups to enhance the strategic definition of corporate social responsibility. Nevertheless, engaging specific stakeholders requires their identification and classification. Based on the role stakeholders play and the influence they have on the performance of a company, they can be grouped as primary and secondary stakeholders. Primary stakeholders include employees, customers, investors, suppliers, all are essential for a company’s survival. However, while secondary stakeholders 
such as the media, trade associations, non-governmental organizations, along with other interest groups have less influence on the company’s performance, these stakeholders may have enough power to influence business direction and performance. Maignan, Ferrell, and Ferrell (2005) state that a variety of stakeholders can exercise pressure on firms to demand actions in favour of their separate interests. In reply, a company’s approach towards stakeholder pressure affects the effectiveness of that response. Koll, Woodside, and Mühlbacher (2005) find that a balanced response to all stakeholders is required, (instead of focusing on a single stakeholder), thus the effectiveness of the organization's responsiveness overall, is enhanced.

While the focus of corporate citizenship has often been due to a single organization in the value chain, Waddock (2004, p.32) argues for a "holistic and integrated responsibility assurance system," to make corporate social responsibility real. Therefore, as companies have a variety of stakeholders satisfying these key stakeholder groups becomes a priority. Just which stakeholder receives attention is decided by the one that has the greatest impact on the bottom-line of business (Greenley, Hooley, Broderick, \& Rudd, 2004). Prioritizing company's resources based on the expected financial impact, from a social responsibility perspective, is construed as a reactive and a rather utilitarian strategy which explains why corporate citizenship is seen only as a marketing tool to increase profitability, rather than an honest set of corporate actions taken because the company favours doing good above making profits only (Phillips \& Caldwell, 2005). Thus the idea of transparency within the objectives of the strategy requires to be considered and be seen to lend support to the corporate associations of trust and goodwill. 
Psychologists who have been studying integrity for more than 50 years conclude that the construct of honesty and integrity remains vague and ill-defined and that empirical evidence seeking to validate the concept is not compelling (Rieke \& Guastello, 1995). From a supply chain perspective transparency is suggested to be important in enhancing integrity and performance of relationship between parties and this implies a high degree of trust. Integrity and trust are intertwined constructs; trust has been extensively studied, however, integrity has been studied only as a dimension of trust. Trust, in a between-business situation does not allow to separate social from economic systems as (Möllering, 2002), thus affects supplier selection from a purely efficiency-driven mode, which may not be consistent with the value chain approach. However, Lamming, Caldwell, Harrison, and Phillips (2001) propose advancing cost transparency to value transparency where value is enhanced when two parties do business within a case-specific transparent chain. New (2010) argues that transparency should not only be between two parties, instead customers (or stakeholders) should know everything about the product from the company; because they will discover it anyway. This research again tends to reinforce the need for trust building, and thus maximum integrity within any sustainability strategy.

As stakeholders' expectations grow, the age old argument that some parties are better kept at arm's length is no longer effective in dealing with the new stakeholder business reality. In fact, some firms are afraid that a focus on social responsibility may open a Pandora's Box, and their resources will be unable to cope with the solutions required to fixing what they find. So, they stall on reacting to stakeholder pressure. While Hilson and Murck (2000) argue that no single blueprint for sustainability exists, and that from a country perspective, sustainability is approached differently for different economic and political systems, to improve CSR 
effectiveness, the parties' commitment to collaboration and the alignment of social, environmental and economic goals, is becoming necessary.

It is still unclear how companies respond to demands of diverse stakeholder groups whether they are primary or secondary, and if such responsiveness is effective for businesses' longterm viability. Neither it is clear what stakeholders companies should focus on, and what kind of actions improve and which worsen the probabilities of their CSR strategies's longer-term success?

Until know, social responsibility programs were thought to promote sustainability, however, it is becoming clearer that a CSR program in itself is not enough to achieve companies' sustainability strategies, because of the wider issues of inclusivity of value chain partners within the chain, as well as the ultimate integrity of the CSR program itself.

While the intent of CSR programs is adding to corporate reputation (Williams, Buttle \& Biggemann, 2012), the actual value delivered by CSR projects is difficult to assess, furthermore the identification of how sustainability value is distributed and made sustainable is equally fraught, thus the need to assess stakeholders' active participation as well their commitment, is becoming more apparent. Thus this research aims to shed light to a more comprehensive pathway for companies to work with stakeholders in order to build sustainability more cohesively into their businesses.

\section{Methodology}

This research is based on two embedded case studies as defined by Yin (2003). The first case study was in a large mining company operating in New Zealand, where the main focus of the 
study has been on the effects of the company's relationships with stakeholders on sustainability. Multiple strategies for data gathering were utilised. These include sustainability development practices in the context of the mining industry in the region, published reports from the mining company's website and affiliated stakeholder websites, as well as online search in news articles used in determining their stakeholder groups. The second stage consisted of interviewing two company's field managers working on sustainability and five key stakeholder groups. The informants of the in-depth interviews were key decision makers, representing their organisation with expertise in the sustainability arena of their organisations. All participants had extensive levels of knowledge of the working relationship between the stakeholder groups and the mining company or vice versa. The second case study was based on the New Zealand Merino Company with headquarters in Christchurch, New Zealand. They are an integrated marketing and sales facilitator for the New Zealand merino wool industry. NZM is a key link in the value chain that provides through brokering contracts for merino wool, value in research and development, quality control on the farms, marketing research and co-development of brands with retailers. They also work with offshore manufacturers to increase the reliability as well as the ethical behaviours of those manufacturers. Eight semi-structured interviews lasting in average one hour were conducted; four within the company, two with retailers, and two with wool growers. Manufacturers, located in China, were not included in the research as the company did not allow the researchers to contact manufacturers for reasons of confidentiality. Senior and key account managers and owners were the typical interviewees. In both case studies, informants were briefed about the research purposes before the interview. This procedure proved to be useful because then the researcher did not need to continuously prompt the informant regarding the research topic. Hence bias due to interviewer intrusion was 
minimised. Interviews were tape-recorded and fully transcribed for analysis. Thematic networks were used for data analysis.

Attride-Stirling (2001) argues that the thematic networks technique is a robust tool for analysing qualitative data. The process is: code materials, identify themes, construct thematic networks, explore thematic networks, and interpret patterns. There are three elements in thematic networks: the global themes, organising themes and basic themes. Basic themes are the lowest-order themes derived from textual data. Organising themes are middle-order themes that organise basic themes clustering them, and global themes are super-ordinate themes that resume the principal content of the whole data set. The use of thematic networks for data analysis helps the researcher to look beyond the basic themes to ones more deeply imbedded in the data. Interviewees were prompted to define integrity and value at a both a personal and industry level. No specific questions were asked, instead probes were utilised to encourage informants to continue building on the topic, giving examples in illustration of their points.

\section{Case study 1}

The mining company has a sustainability project that basically consists of the implementation of individual projects targeting sustainable development for beneficiaries that are organizations in the surrounding local community. The company aims to build a relationship with key stakeholders through these projects. The company considers that these relationships have the potential of promoting sustainable development in the region and therefore foster their own intentions of achieving business sustainability. Three relevant projects related to each one of the stakeholder groups are identified. Stakeholder group 1 is associated to a project of landscape rehabilitation; stakeholder group 2 is associated to a trout hatchery 
project, and stakeholder group 3 is associated to a heritage and art park development. The effects of establishing these three projects were different.

We started our interviews asking the definition of sustainability. Not surprisingly our informants had different definitions for sustainability. For instance, representatives of the surrounding community define sustainability as "Environmental stuff, like...eco-friendly dishwashing liquid” whereas the local Maori community, Renuaka’s definition of sustainability has a broader scope that includes the environment but also influences people's lives for the better, "My interpretation of sustainability is that after mined, life it is returned to better than it was prior to. That's my idea of sustainability.” The company's definition of sustainable development is very much environmentally related and also associated to the end of the mining activity, “We've got to focus on sustainable development, but that's when the mine closes the area will still have some sustainable thing.” Although the regional council focuses on the environment their definition of sustainability also includes a view for the future and current economic development, "It's really the balance between economic development and environmental, sustaining the environment or the ecosystem for future generations.” In a second thought Renuaka adds, “Another interpretation of sustainability is that it provides employment for the local people- that's sustainable too" denoting that sustainability includes a current economic component that benefits members of their group and other stakeholders, and secures their long term welfare.

Looking at the parties' assessment of their relationships we found some important differences. Renuaka's assessment of their relationship with the company is, “Oh, we've had our ups and downs” whereas the company qualifies their relationship with Renuaka as, “Positive relationship...it's generally quite good.” The company's over optimistic view may prevent them for seeking further opportunities to promote sustainable development with this group. Regarding the relationship with the regional council that qualifies it as, "Well, from 
my point of view it's very arms' length and regulatory.” A company spokesperson reports, "Yeah. They're all good;” a slightly more optimistic response to that of their counterpart. Regarding interest group 2 the company qualifies their relationship, “We’ve got a pretty good relationship with [Interest Group 2].”

In our interpretation of these data, we see three different levels of good, of which the relationship with interest group 2 is the most positive. In terms of responsiveness to the needs of stakeholders the company shows a rather reactive approach. That is, they only take action when a stakeholder complains and problems become significant. In illustration, the company implemented a project for the construction of a tail dam triggering a number of complaints from stakeholders. Thus Renuaka wants to be consulted before the company starts with any activity in the area. If they are not consulted, as happened with this project, then they become upset and less cooperative. However, the company only approached Renuaka to consult their opinion after they faced local opposition.

A more successful project is the fish hatchery. However, the company’s support of the hatchery project was also the consequence of interest group 2's initial actions. Nevertheless, interest group 2 is more satisfied with the company because the hatchery project delivers significant benefits, thus they perceive this project to be mutually beneficial. A mining company spokesperson stated, "We had an employee here that loved fish... he was a voluntary ranger, and so he heard that [Interest group 2] were closing down a hatchery in Wanaka and he thought here would be a really good place so he, sort of, put the idea to us and the environment team.” Whereas a spokesperson from the community (Interest Group 2) group said, "A proposal that went to the mining company at about the same time as the mining company was looking to do something green... they had a part of their consents which required them to maintain sort of like a sustainable community in the area." 
In the end both parties are satisfied. Interest Group 2 because they have now a place to hatch fish. As this quote illustrates, "Our trout hatchery is really a feel good project." Thus the company is also satisfied. What is more, the company uses this project as a demonstration of mitigation activities that the council acknowledges as positive.

Seven stakeholder groups were identified, each of which had a different type of relationship with the mining company as well as different views of what sustainability means. Table 1 summarises these relationships.

Table 1. The Mining Company Sustainable Development Analysis

\begin{tabular}{|c|c|c|c|}
\hline Stakeholder Group & $\begin{array}{l}\text { Relationship stakes } \\
\text { (value) }\end{array}$ & $\begin{array}{l}\text { Description of } \\
\text { Sustainable } \\
\text { Development }\end{array}$ & Nature of relationship \\
\hline $\begin{array}{l}\text { Department of } \\
\text { Conservation }\end{array}$ & $\begin{array}{l}\text { Value the conservation of } \\
\text { the environments, animals } \\
\text { and vegetation }\end{array}$ & $\begin{array}{l}\text { The company works } \\
\text { closely with the } \\
\text { department in identifying } \\
\text { and protecting mining and } \\
\text { pastoral heritage that is } \\
\text { not in the path of the } \\
\text { mining footprint }\end{array}$ & $\begin{array}{l}\text { Arm's length } \\
\text { Neutral } \\
\text { Established in1989 }\end{array}$ \\
\hline Local Maori Renuaka & $\begin{array}{l}\text { Maori group who has } \\
\text { traditionally had } \\
\text { responsibility for the land } \\
\text { on which the mining } \\
\text { company's project is } \\
\text { located }\end{array}$ & $\begin{array}{l}\text { A memorandum } \\
\text { recognises this } \\
\text { relationship and identifies } \\
\text { the consultation process to } \\
\text { be followed when } \\
\text { developing the operations } \\
\text { in the mining area that } \\
\text { encourages continued and } \\
\text { open dialogue with the } \\
\text { Local Maori Renuaka }\end{array}$ & $\begin{array}{l}\text { Arm's length } \\
\text { Neutral } \\
\text { Some cases negative } \\
\text { attitude expressed } \\
\text { Formalised } 2004\end{array}$ \\
\hline $\begin{array}{l}\text { The Surrounding } \\
\text { Community } \\
\text { a. School } \\
\text { b. Businesses } \\
\text { c. Locals }\end{array}$ & $\begin{array}{l}\text { The surrounding } \\
\text { community and what } \\
\text { happens after mining life. }\end{array}$ & $\begin{array}{l}\text { There is one hotel, an } \\
\text { information centre on the } \\
\text { mine and local history, } \\
\text { five local houses, a } \\
\text { community hall and fire } \\
\text { station. } \\
\text { Schools- funding and } \\
\text { educates them about the } \\
\text { mining process } \\
\text { Businesses NA }\end{array}$ & $\begin{array}{l}\text { Some apathetic } \\
\text { Some positive at what the } \\
\text { mining company does for } \\
\text { the community } \\
\text { Established } 1989\end{array}$ \\
\hline
\end{tabular}




\begin{tabular}{|c|c|c|c|}
\hline & & Locals NA & \\
\hline Regional Council & $\begin{array}{l}\text { Regulates water } \\
\text { catchments, and disposal } \\
\text { operations for the good of } \\
\text { the Region }\end{array}$ & $\begin{array}{l}\text { Abides to water } \\
\text { catchment, and disposal } \\
\text { regional laws } \\
\text { The company maintains } \\
\text { close relationships with } \\
\text { all councils through their } \\
\text { regular site visits and on- } \\
\text { going consultation }\end{array}$ & $\begin{array}{l}\text { Arm's length } \\
\text { Neutral } \\
\text { Established } 1989\end{array}$ \\
\hline $\begin{array}{l}\text { Stakeholder Group } \\
\text { Interest Group } 1\end{array}$ & $\begin{array}{l}\text { Protecting native plants, } \\
\text { animals and species, on } \\
\text { land and in oceans }\end{array}$ & $\begin{array}{l}\text { 350ha has been } \\
\text { rehabilitated as wetlands } \\
\text { or restored as grazing } \\
\text { land. Local field officer } \\
\text { for Forest and Bird had } \\
\text { not monitored progress on } \\
\text { the rehabilitation } \\
\text { programme }\end{array}$ & $\begin{array}{l}\text { Interest activist group } \\
\text { Neutral attitudes and } \\
\text { some negative }\end{array}$ \\
\hline $\begin{array}{l}\text { Stakeholder Group } \\
\text { Interest Group } 2\end{array}$ & $\begin{array}{l}\text { Value water catchments } \\
\text { to be of sufficient value to } \\
\text { pursue angling, e.g. from } \\
\text { fish spawning- to the level } \\
\text { of water in the catchment }\end{array}$ & $\begin{array}{l}\text { Trout Hatchery, } \\
\text { maintained and sponsored } \\
\text { by mining company. The } \\
\text { Hatchery raises an } \\
\text { average of } 10,000 \text { to } \\
12,000 \text { rainbow trout } \\
\text { annually for release into } \\
\text { "put and take" fisheries } \\
\text { throughout Region } \\
\text { (fisheries which have no } \\
\text { natural spawning and } \\
\text { therefore are not self- } \\
\text { sustaining). }\end{array}$ & $\begin{array}{l}\text { Partnership } \\
\text { Positive } \\
\text { Established } 2004\end{array}$ \\
\hline $\begin{array}{l}\text { Stakeholder Group } \\
\text { Interest Group } 3\end{array}$ & $\begin{array}{l}\text { Protection and } \\
\text { preservation of historical } \\
\text { sites and artefacts }\end{array}$ & $\begin{array}{l}\text { They work together to } \\
\text { ensure the exploration and } \\
\text { mining activities have } \\
\text { minimum impact on } \\
\text { heritage sites or artefacts. }\end{array}$ & $\begin{array}{l}\text { Arm’s length } \\
\text { Neutral, positive } \\
\text { Established } 1989\end{array}$ \\
\hline
\end{tabular}

Three key projects that include, Rehabilitation projects, The Heritage and Art Park development, and The Trout Hatchery have been the main sustainable development projects for the mining company. Both rehabilitation projects and the Heritage and Art Park are seeing as rather low success projects while the Trout Hatchery is perceived as a highly successful project. Arguably, the Hatchery is perceived as of higher success because the project originated in the community, whereas the other two projects were the initiative of the 
company. This suggests that the community perceives co-created value as higher than company created value.

Summing up Case study 2, establishing a project with stakeholders has positive effects but not sufficient to secure sustainability long term, perception of value is as important as actual benefits. All three projects were beneficial to their stakeholders. However, the most satisfying was the project with Interest Group 2 because of the project ownership and the perceived cocreation of value and share of benefits.

\section{Case study 2}

The focal company on Case study 2 designs and markets high end merino clothes in the New Zealand and international markets. The focus of the study was on the relationship between the company and their stakeholders. The company construes sustainability as a consequence of being socially responsible, which is only achievable through integrity. The company defines integrity as, "more than the tip of the iceberg, it is instead the whole iceberg that includes everything about the product and is underpinned with credibility." Driven by the company's definition of sustainability we focused our enquiry on integrity, finding that other members of the value chain shared the company's idea of sustainability as the consequence of integrity. A wool grower explained, "the product we deliver is what we say it is and that we are not hiding or being un-truthful about any aspect of production of that product." A retailer also justified the importance of having nothing to hide, "We are getting bigger and bigger, as people are getting more conscious about where their clothing is coming from, and the practices made to make it.”

An interest group that may have the ability to affect the wool company's success is PETA (People for the Ethical Treatment of Animals). They are an organisation that advocates for and promotes the need for animal welfare. Although raising merino sheep is not the 
responsibility of the company, their focus on social responsibility is also about ethical issues related to the wellbeing of animals. NZM keeps an eye on the quality assurance processes in place to secure fibre quality for their final products. The company works alongside SAFE (Save Animals From Experiments) an organization dedicated to protect animals that provides their brand to organisations that raise animals in an ethical and responsible manner. The company advocates one of the major challenges in merino farming, which is to reduce the practice of mulesing. A premium brand offered to a limited number of retailers that meet strict guidelines about socially responsible practices, as well as having values that are similar to that of the company and the merino growers of New Zealand as a whole, who require the farm to have ceased mulesing or to have never mulesed. In this way, New Zealand merino is distinguished from Australian merino where mulesing, although controversial and considered as animal cruelty, is still common practice.

Essential to maintaining integrity it is to 'get processes right from the start'. Integrity provides the company with a marketing tool too. End consumers are provided with a unique swing tag, which allows customers to trace their purchase back to the farm that the sheep were raised, and thus the origins of the wool used to knit their garments. Therefore, not only do retailers gain a benefit from wool growers farming in a sustainable way, wool growers also realise the benefits. Integrity generates value for growers because it reinforces the way they look at their activity. A wool grower says, “[Farming], it's more than a business, it's a privilege and we want to make a living of it.” Integrity also delivers value for retailers because it is believed that consumers are willing to pay a premium for the integrity of the company’s products. Within the company informants believe integrity creates a sense of pride and personal ownership of the brand. For example, a company spokesperson states, "It gives them a sense of pride about where their products end up." A grower adds, "Instead of 
just growing wool, we're actually growing it for an end-producer and for an end-consumer. Retailers participate of the whole creation of value. They are invited to visit the farms where the wool is produced and encouraged to share their experiences with end consumers. The company does not pay the growers any higher than market price, thus, the value created in the process arguably goes beyond financial considerations. Thus making profits is a necessary condition but not the whole reason for being in business. A respondent of the company explains, "Pride is to me, an equal [to money] and for growers as well, pride is a big thing.” Both growers and the company feel that non-monetary value adds 'fullness and meaning' to what they do for a living. However, retailers see this differently, they place money at a higher priority. A retailer called money, 'the driving factor'

Summing Case study 2 up it could be argued that sustainability for them goes beyond environmental concerns. Although animal welfare is central, sustainability is grounded on the superior concept of integrity, in which the pride that parties feel in being part of the value chain, is a fundamental. Pride promotes collaboration and reduces bargain and opportunistic behaviour. Pride in Case study 2 is critical in value generation, however, pride could not exist if integrity is broken.

\section{Discussion}

While Whitmore (2006) argues that behind the miners' rhetoric of sustainability lies the same old financial ambition, Case study 1 shows that the implementation of a project, proposed by and beneficial to the stakeholder worked as the starting point for the company in building a relationship with stakeholder 2, a relationship that delivers value for both parties beyond the benefits of the project. Based on Söllner’s (1999) commitment typology it could be argued that the employee's sharing of information with the company about the opportunity to build a fish hatchery was an attitudinal input towards commitment. However, from the point of view of Interest Group 2, the company’s response to financing the infrastructure was an 
instrumental input towards commitment. This created a solid structure of relationships that improved through the interaction between the parties which has reinforced economic bonds as well (Holmlund \& Törnroos, 1997). Thus the mutual interdependence of the parties makes the businesses evolve together. The project fosters business sustainability for the mining company because it demonstrates a mitigation activity of the adversarial effects that mining operations invariably create. While for Group 2 the project has economic relevance because the fish hatchery is fundamental for their activity. However, if it were not for that one member's actions in Group 2 who worked at the company, initiating this project might not have been possible. This mutually beneficial initiative illustrates the importance of the intertwinement that exists between a company and its stakeholders. The case supports (Koll, Woodside, \& Mühlbacher, 2005) who argue that the responsiveness of one party to the benefits of the other creates value for both.

In contrast, within the relationship between the company and the Maori community Reanuka, the lack of consultation about the tail dam project had a worsening effect on trust honesty, the belief that the other party will be credible (Ganesan, 1994). Less trust between the parties is detrimental to business performance.

In Case study 2 sustainability is grounded in integrity. Rieke and Guastello (1995) argue that although psychologists have been studying integrity for more than 50 years the empirical evidence seeking to validate the concept is not compelling. However, evidence in Case study 2 suggests that integrity is built on consistency, trust and pride, concepts that allow for a clearer understanding of integrity. Consistency keeps integrity stable (McFall, 1987), Trust decreases the perception of risk when interacting with other party. However, pride is about having high praise and dedication towards the values that products and services stand for, as well as having pride in the work being carried out and the relationships then forged 
throughout the value chain. Pride needs no enforcement. This view of integrity contrasts with Becker’s (1998) views of integrity who argues that integrity requires rationality. Thus reason, not emotion, should be the primary guide of individuals. Notwithstanding, individuals may lack integrity because of inconsistencies between desires and moral values, because individuals succumb to social pressure.

However, understanding that pride is a constituent part of integrity, demonstrates that the inconsistency between desires and moral values cannot coexist easily in integrity-driven value chains. NZM's business sustainability is enhanced because of the pride that everyone in the chain experience to be part of the process of merino wool marketing. This shows the importance of business goals and values being aligned alongside the chain. Likewise, this reflects the findings of Iseda (2008) in that pride is an intangible benefit to an organisation that attenuates issues with work ethics, creates higher moral standards and increases the integrity of individuals’ work. Hume (1911) refers to pride as a positive feeling towards oneself that can be considered a vice or a virtue. In the context of integrity it is considered a virtue as it leads to the parties' increased self-esteem and therefore happiness associated to be part of the value chain.

The difference between the mining company and NZM in their approach towards sustainability is evident. While the mining company adopts a reactive stance and only takes action when a stakeholder complains or comes up with an interesting proposition, NZM focuses in value creation with most stakeholders of the organization and has managed to build a value chain with integrity. The idea of the value chain, as exposed by Porter (1985) focuses on the efficiencies in the processes of transformation until the end consumers' needs are met at a profit, thus the main focus is on economic value. However, value in this research goes beyond economic considerations, value is derived from what is gained from using money, not only the fact of having the money. Value is also hedonic, like the peace of mind 
that growers find in working with NZM, because NZM guarantees a stable price for wool. Value is also symbolic for farmers that define their activity as a privilege; while being functional for retailers that can guarantee integrity alongside the overall chain. Manifestations of value in this research are consistent with the framework that assesses value, proposed by Smith \& Colgate (2007). Further it reinforces Maignan, et al.’s (2005) call for a stakeholder orientation that aims to understand and address all stakeholders' demands, beyond markets, competitors and channel members.

\section{Conclusions}

Sustainability has several dimensions including economic, ecological, and social. As companies are part of extended networks, they are related to multiple stakeholders. Sustainability strategies need to include all stakeholders, bearing in mind, that most stakeholders are different regarding the demands they make, their abilities to influence the course of action, and their expectations. Thus, companies' responsiveness towards the demands of different stakeholders should be different too. Sustainability strategies must be stakeholder inclusive.

This research also shows that interaction affects the structure of the relationship between the parties for better or worse. The dimensions of relationship structure that empirical data of this research demonstrate have suffered change are: trust, commitment, and bonds. However, because integrity is composed of consistency, trust, and pride, it is also affected by the structure of relationship, even though integrity is supposed to affect business sustainability. The role of integrity observed in Case study 2 is such that suggests that sustainability is achievable with less instrumental inputs towards a relationship, such as those normally associated with CSR programs. Integrity is more efficient in building commitment between 
the parties. Hence, conscious efforts to enhance value chain integrity could pay off in the form of increased business performance, by building in sustainability more productively than most CSR programs, which research suggests carry costs, but do not deliver value.

\section{Managerial Implications}

Company managers should not ignore the importance of building in sustainability into their businesses. They need to respond to stakeholders’ demands, however proactively, as opposed to reactively. Sustainability goes beyond environmental issues. While CSR is closely associated with achieving integrity, as Ebner and Baumgartner (2006) suggest, CSR activity should include economic, ecologic and social aspects. Social responsibility initiatives should focus on the benefits delivered by all parties in the value chain. That is, CSR should be about value creation. The effects of integrity on achieving more profitable business outcomes are such that companies should find increased motivation to demonstrate and pursue integrity alongside the whole value chain. Even a mining company should be able to instil pride in their stakeholders, not only because of the product they market, but because of the beneficial relationships that can be built, the value that this activity creates, and thus the benefits derived, with others, within their networks.

\section{Acknowledgments}

The authors thank Julie Aitken and Alex Gibbons for their help with the data collection.

\section{References}

Anderson, J. C., Kumar, N., \& Narus, J. A. (2007). Value merchants: demonstrating and documenting superior value in business markets. Boston: Harvard Business School Press.

Attride-Stirling, J. (2001). Thematic networks: an analytic tool for qualitative research. Qualitative Research, 1(3), 385-405. 
Baumgartner, R. J., \& Ebner, D. (2010). Corporate Sustainability Strategies: Sustainability Profiles and Maturity Levels. Sustainable Development, 18(2), 76-89.

Becker, T. E. (1998). Integrity in organizations: beyond honesty and conscientiousness. Academy of Management Review, 23(1), 154-161.

Borys, B., \& Jemison, D. B. (1989). Hybrid Arrangements as Strategic Alliances: Theoretical Issues in Organizational Combinations. Academy of Management Review, 14(2), 234249.

Bowd, R., Bowd, L., \& Harris, P. (2006). Communicating corporate social responsibility: an exploratory case study of a major UK retail centre. Journal of Public Affairs, 6(2), 147-155.

Buysse, K., \& Verbeke, A. (2003). Proactive Environmental Strategies: A Stakeholder Management Perspective. Strategic Management Journal, 24(5), 453-470.

Carroll, A. B. (1979). A Three-Dimensional Conceptual Model of Corporate Performance. Academy of Management Review, 4(4), 497-505.

Clarkson, M. B. E. (1995). A Stakeholder Framework for Analyzing and Evaluating Corporate Social Performance. Academy of Management Review, 20(1), 92-117.

Ebner, D., \& Baumgartner, R. J. (2006). The relationship between Sustainable Development and Corporate Social Responsibility. Paper presented at the Corporate Responsibility Research Conference 2006, 4th-5th September, Dublin.

Flint, D. J. (2006). Innovation, symbolic interaction and customer valuing: thoughts stemming from a service-dominant logic of marketing. Marketing Theory, 6(3), 349362.

Friedman, M. (1962). Capitalism and freedom. Chicago: Chicago U.P.

Ganesan, S. (1994). Determinants of Long-Term Orientation in Buyer-Seller Relationships. Journal of Marketing, 58(April), 1-19.

Greenley, G. E., Hooley, G. J., Broderick, A. J., \& Rudd, J. M. (2004). Strategic planning differences among different multiple stakeholder orientation profiles. Journal of Strategic Marketing, 12(3), 163-182.

Harrison, T. P., Lee, H. L., \& Neale, J. J. (Eds.). (2005). The practice of supply chain management: where theory and application converge. Norwell, MA: Springer.

Hilson, G., \& Murck, B. (2000). Sustainable development in the mining industry: clarifying the corporate perspective. Resources Policy, 26(4), 227-238.

Holbrook, M. B. (Ed.). (1999). Consumer value: a framework for analysis and research. London: Routledge.

Holmlund, M., \& Törnroos, J.-Å. (1997). What are relationships in business networks? Management Decision, 35(4), 304-309.

Hume, D. (1911). A treatise of human nature. London: J M Dent \& sons ltd.

Iseda, T. (2008). How should we foster the professional integrity of engineers in Japan? A pride-based approach. Sci Eng Ethics, 14(4), 165-176.

Koll, O., Woodside, A. G., \& Mühlbacher, H. (2005). Balanced versus focused responsiveness to core constituencies and organizational effectiveness. European Journal of Marketing, 39(9/10), 1166-1183.

Lamming, R. C., Caldwell, N. D., Harrison, D. A., \& Phillips, W. (2001). Transparency in supply relationships: Concept and practice. Journal of Supply Chain Management, 37(4), 4-10.

Maignan, I., Ferrell, O. C., \& Ferrell, L. (2005). A stakeholder model for implementing social responsibility in marketing. European Journal of Marketing, 39(9/10), 956-977.

McFall, L. (1987). Integrity. Ethics, 98, 5-20.

Menon, A., \& Menon, A. (1997). Enviropreneurial Marketing Strategy: The Emergence of Corporate Environmentalism as Market Strategy. Journal of Marketing, 61(1), 51-67. 
Miles, M. P., Munilla, L. S., \& Darroch, J. (2006). The Role of Strategic Conversations with Stakeholders in the Formation of Corporate Social Responsibility Strategy. Journal of Business Ethics, 69(2), 195-205.

Möllering, G. (2002). Perceived trustworthiness and inter-firm governance: empirical evidence from the UK printing industry. Cambridge Journal of Economics, 26(2), 139-160.

New, S. (2010). The Transparent Supply Chain. Harvard Business Review, 88(10), 76-82.

Phillips, R., \& Caldwell, C. B. (2005). Value Chain Responsibility: A Farewell to Arm's Length. Business and Society Review, 110(4), 345-370.

Porter, M. E. (1985). Competitive advantage: creating and sustaining superior performance. New York: Free Press.

Porter, M. E., \& Kramer, M. R. (2011). Creating Shared Value. Harvard Business Review, $89(1 / 2), 62-77$.

Prahalad, C. K., \& Ramaswamy, V. (2004). The future of competition : co-creating unique value with customers Boston: Harvard Business School Publishing.

PriceWaterhouseCoopers. (2008). From vulnerable to valuable: How integrity can transform a supply chain. www.pwc.com/us/en/supply-chain-management/publications/suplychain-report-download.html

Ramaswamy, V. (2008). Co-creating value through customers' experiences: The Nike case. Strategy \& Leadership, 36(5), 9-14.

Rieke, M., \& Guastello, S. (1995). Unsolved Issues in Honesty and Integrity Testing. American Psychologist, 50(6), 458-459.

Salzmann, O., Ionescu-Somers, A., \& Steger, U. (2005). The Business Case for Corporate Sustainability: Literature Review and Research Options. European Management Journal, 23(1), 27-36.

Sandström, S., Edvardsson, B., Kristensson, P., \& Magnusson, P. (2008). Value in use through service experience. Managing Service Quality, 18(2), 112-126.

Smith, J. B., \& Colgate, M. (2007). Customer Value Creation: A Practical Framework. Journal of Marketing Theory \& Practice, 15(1), 7-23. doi: 10.2753/mtp10696679150101

Söllner, A. (1999). Asymmetrical Commitment in Business Relationships. Journal of Business Research, 46(3), 219-233.

Spence, L., \& Bourlakis, M. (2009). The evolution from corporate social responsibility to supply chain responsibility: the case of Waitrose. Supply Chain Management: An International Journal, 14(4), 291-302.

Thorelli, H. B. (1986). Networks: Between Markets and Hierarchies. Strategic Management Journal, 7, 37-51.

Vargo, S. L. (2008). Customer Integration and Value Creation: Paradigmatic Traps and Perspectives. Journal of Service Research, 11(2), 211-215.

Waddock, S. (2004). Parallel Universes: Companies, Academics, and the Progress of Corporate Citizenship. Business and Society Review, 109(1), 5-42.

Whitmore, A. (2006). The emperors new clothes: Sustainable mining? Journal of Cleaner Production, 14(3-4), 309-314.

Yin, R. K. (2003). Case Study Research: Design and Methods (Third ed. Vol. 5). Thousand Oaks: Sage Publications. 